\title{
PENGARUH SISTEM PEMBELAJARAN FULL DAY SCHOOL TERHADAP PEMBENTUKAN KARAKTER RELIGIUS SISWA SIT AL-BIRUNI MANDIRI MAKASSAR
}

\author{
Nurmaidah Rahman ${ }^{1}$, A. Octamaya Tenri Awaru ${ }^{2}$ \\ ${ }^{1,2}$ Pendidikan Sosiologi-FIS UNM \\ maidahrahman@gmail.com¹, a.octamaya@unm.ac.id ${ }^{2}$
}

\begin{abstract}
ABSTRAK
Penelitian ini adalah penelitian kuantitatif yang bertujuan untuk mengetahui ada tidaknya pengaruh sistem pembelajaran full day school terhadap pembentukan karakter religius siswa SIT Al-Biruni Mandiri Mandiri Makassar. Variabel bebas dalam penelitian ini adalah full day school, sedangkan variabel terikatnya karakter religius. Populasi dalam penelitian ini adalah siswa Sekolah Menengah Pertama (SMP) dan siswa Sekolah Menengah Atas (SMA) di SIT Al-Biruni Mandiri Makassar tahun ajaran 2018/2019 yang berjumlah 105 orang siswa, sedangkan sampelnya yaitu sebanyak 83 orang yang diambil dari 6 kelas Sekolah Mengah Pertama (SMP) dan 3 kelas Sekolah Menengah Atas (SMA) ditentukan melalui teknik probability sampling dengan menggunakan sampling acak sederhana (simple random sampling), dengan kriteria informan yaitu siswa yang rajin. Teknik pengumpulan data yang dilakukan yaitu kuesioner/ angket, observasi, dan dokumentasi. Teknik analisis data menggunakan uji prasyarat analisis yaitu uji nomalitas, uji homogenitas, uji parsial (uji T), analisis regresi sederhana dan analisis korelasi linier. Hasil penelitian menunjukkan bahwa variabel $X$ (full day school) berpengaruh terhadap variabel Y (Religius) pada siswa SIT Al-Biruni Mandiri Makassar. Hal tersebut ditunjukkan dari hasil analisis product moment sebesar 0,751 dibandingkan dengan $r_{-}$tabel tingkat signifikan 5\% N=83 sebesar 0,215. Jadi $r_{-}$hitung besar dari $r_{-}$tabel, maka dapat ditarik bahwa hipotesis nol (Ho) ditolak dan (Ha) diterima. Dengan koefisien determinasi variabel $X$ terhadap variabel Y sebesar 56,40\% dan selebihnya yang 43,6\%, ini berarti sistem full day school berperan dalam pembentukan sikap religius siswa. Dari hasil penelitian, saran bagi pihak sekolah agar meningkatkan lagi pencapaian tujuan sekolah dengan mengadakan monitoring dan evaluasi pelaksanaan sistem full day school. Kemudian untuk siswa agar selalu menambah pembiasaan karakter religiusnya baik disekolah atau di luar sekolah agar lebih baik lagi. Tidak lupa juga untuk orangtua agar selalu mengarahkan anaknya dalam beribadah sehingga apa yang sudah di dapatkan di sekolah tetap terlaksana ketika di luar sekolah, karena orang tua adalah orang terdekat siswa selain di lingkungan sekolah.
\end{abstract}

Kata kunci: Full day school, karakter religius.

\begin{abstract}
This research aims to know weather the learning system of Full Day school have effect towards students' religious character building of SIT Al-Biruni Mandiri Makassar. Kind of research was quantitative research. The numbers of population were the students of Junior High School and Senior High School of SIT Al-Biruni Mandiri Makassar in 2018/2029 Academic Year. They were 105 respondents as population while there were 83 respondents as sample that taken from 6 classes in Junior High School and 3 classes in Senior High School. It applied probability sampling in simple random sampling with the diligent students' criteria. Data collection techniques were questionnaire, observation, and documentation. Data analysis technique used the prerequisite analysis namely the normality test, homogeneity test, partial test (T test), simple regression analysis and linear correlation analysis. The results of research showed that variable $X$ (full day school) affected Y (religious) variable in the students of SIT Al-Biruni Mandiri Makassar. This was indicated from the results of the product moment analysis of 0.751 compared to $r_{-}$table a significant level of $5 \% \mathrm{~N}=$ 83 of 0.215. So, $r_{-}$count from $r_{-}$table. It showed that the null hypothesis (H0) was rejected and (Ha) was accepted. With the determination coefficient of variable $X$ to $Y$ variable of $56.40 \%$ and the remaining of 43.6\%, It meant that the full day school system played a role of students' religious attitude building. From the results of the research. As suggestions for the school to increase the achievement of school goals more by monitoring and doing evaluation of the implementation of the full day school system. Then for students always increase the habituation of their religious character both in the school and outside the school to make that to be better. Also, do not forget for the parents always ask their children in worship so that what had been taught at school, it is still done when they are outside of school, because parents are the closest people for students beside the school environment.
\end{abstract}

Keywords: Full day school, religious character. 


\section{PENDAHULUAN}

Membicarakan karakter merupakan hal yang sangat penting dan mendasar. Zubaedi mengungkapkan bahwa karakter adalah mustika hidup yang membedakan manusia dengan binatang. Manusia tanpa karakter adalah manusia yang sudah "membinatang" (Zubaedi, 2011). Orang-orang yang berkarakter kuat dan baik secara individual maupun sosial ialah mereka yang memiliki akhlak, moral dan budi pekerti yang baik. Mengingat begitu pentingnya suatu karakter, maka lembaga pendidikan memiliki tanggung jawab untuk menanamkannya melalui proses pembelajaran.

Saat ini banyak sekali lembaga pendidikan yang memperdalam materi agama agar peserta didiknya bisa menjadi generasi bangsa yang memiliki karakter yang baik. Ini dilakukan untuk menjaga peserta didiknya dari kemerosotan moral dan degradasi moral bangsa. Sehubungan dengan itu, kenakalan remaja berkembang begitu luas sehingga banyak terjadi perbuatan-perbuatan asusila yang terjadi seperti perkelahiann anak sekolah, pembunuhan, pencurian, seks bebas, penggunaan narkoba dan lain-lain. Pengaruh perbuatan tersebut menimbulkan kekhawatiran di dalam keluarga, sekolah dan masyarakat. Dalam hal ini, faktor yang mendominasi terjadinya kemerosotan dikarenakan kurangnya pemahaman dan penghayatan terhadap akhlak, sehingga makin hilangnya nilai-nilai agama dalam kehidupan dan semakin deras arus pergeseran atau dekadensi moral yang terjadi dikalangan masyarakat secara umum, ditambah lagi kurangnya perhatian masyarakat terhadap pendidikan atau pembentukan karakter anak sejak dini (Umah, 2018), (Awaru, 2017).

Dalam hal ini, pembentukan karakter bagi setiap manusia adalah sebuah kewajiban yang harus dilakukan terus menerus tanpa henti baik melalui pembinaan, membiasaan dan hal-hal yang dapat meningkatkan perbaikan karakter seseorang (Awaru et al., 2020). Moralitas merupakan faktor yang esensial. Oleh karena itu, dapat dibayangkan betapa rusaknya generasi bangsa manakala moralitas atau karakter yang dimiliki generasi banyak saat ini mulai menurun. Oleh sebab itu, diperlukan upaya-upaya pembentukan karakter mulai sejak dini agar kelak anak dapat mengetahui mana perilaku yang baik dan perilaku yang buruk. Jadi, pembentukan karakter perlu diimplementasikan pada jalur pendidikan formal maupun non formal.

Gunawan menguraikan bahwa berdasarkan grand design yang dikembangkan kemendiknas, secara psikologi pembentukan karakter dalam diri individu ialah fungsi dari seluruh potensi manusia (kognitif, afektif, dan psikomotorik) (Gunawan, 2012)." Implementasi pembentukan karakter dirasa sangat penting dalam rangka pembinaan generasi bangsa melalui lembaga pendidikan yang menggunakan berbagai upaya untuk menerapkannya. Salah satunya yaitu mengadakan program belajar sehari penuh bagi peserta didiknya atau yang sering dikenal dengan sebutan full day school. Program ini bertujuan untuk membina akhlak dan membentuk karakter yang baik bagi peserta didiknya. Dalam program ini tidak hanya memberi pengetahuan saja akan tetapi juga disertai pembentukan karakter agar peserta didik terbiasa melakukan perilaku-perilaku yang baik dan berakhlak dalam kehidupan sehari-hari.

Full day school adalah salah satu program unggulan yang dirintis oleh beberapa sekolah yang ada di Indonesia. Full day school merupakan sekolah satu harian penuh yang berlangsung mulai pukul 07.00 sampai pukul 15.30 dengan waktu belajar siswa cenderung banyak menghabiskan waktu mereka di sekolah bersama dengan siswa lainnya (As' ari, 2019), (Setyawati \& Torro, 2017). 


\section{Jurnal Sosialisasi \\ Jurnal Hasil Pemikiran, Penelitian, dan Pengembangan Keilmuan Sosiologi Pendidikan \\ Vol 7, Nomor 3, November 2020}

Program ini merupakan sebuah model pendidikan alternatif, di mana peserta didik sehari penuh berada di sekolah untuk melakukan proses pembelajaran dan proses ibadah. Tersedianya waktu yang cukup lama di lingkungan sekolah peserta didik perlahan-lahan akan terbiasa dengan kehidupan yang mandiri dan menumbuhkan sikap kebersamaan dan kesadaran beribadah serta sikap positif lainnya yang dapat menjadikan peserta didik menjadi lebih baik. Program tersebut juga dapat digunakan untuk mengembangkan kreativitas dan bakat yang dimiliki peserta didik.

Asmani menyatakan bahwa point kritis dari sistem pendidikan ini terletak pada biaya yang bisa dikatakan "mahal", jika dibandingkan dengan sekolah pada umumnya. Hal ini terjadi karena kuantitas maupun kualitas pendidikan yang dimiliki jauh lebih bagus (Asmani, 2017). Jadi, full day school ini memiliki sistem pendidikan biaya yang mahal dibandingkan sekolah regular. Hal ini terjadi karena kuantitas maupun kualitas pendidikan yang dimiliki jauh lebih bagus dibandingan sekolah regular. Sebagai program yang tergolong baru, full day school merupakan suatu sistem yang masih asing bagi beberapa sekolahan karena baru sedikit yang menggunakan program tersebut untuk meningkatkan kualitas pendidikan di sekolah masing-masing. Salah satu sekolah yang menerapkan program tersebut adalah SIT Al-Biruni Mandiri Makassar.

SIT Al- Biruni Mandiri Makassar adalah sekolah swasta yang merupakan sekolah islam yang memiliki kualitas baik dan fasilitas yang baik. Tidak hanya dalam bidang agamanya saja, tetapi menjadi yang terbaik dalam segala bidang pendidikan. SIT AlBiruni Mandiri Makassar mendidik peserta didiknya untuk menjadi insan Indonesia yang kreatif, disiplin, mandiri, sadar sholat, berbakti pada orangtua, perilaku sosial baik, tartil baca al-qur'an, hafal juz 'Amma dan berprestasi.

SIT Al- Biruni Mandiri Makassar menerapkan sistem pembelajaran full day school pada hari senin-jum'at dan hari Sabtu peserta didik melakukan aktivitas belajar atau kegiatan bebas di rumah masing-masing. Sejak tahun pelajaran 2013/2014, pemerintah telah menetapkan kurikulum baru yang disebut dengan Kurikulum 2013. Implementasi dalam Permendikbud Nomor 81 A Tahun 2013. Di tahun ajaran 2015/2016 ini, SIT AlBiruni menerapkan Kurikulum 2013 yang dipadukan dengan standar JSIT (Jaringan Sekolah Islam Terpadu) dimana proses belajar mengajar akan dikaitkan dengan nilai-nilai keislaman, beberapa hadits atau ayat-ayat Al Qur'an sehingga siswa memahami bahwa segala sesuatu yang terjadi dimuka bumi ini adalah sunnatullah, sehingga mengarahkan siswa pada pemikiran bahwa semua pelajaran yang akan diterimanya telah terdapat penjelasannya di dalam Al Qur'anul Karim. Dari aktifitas tersebut peserta didik secara perlahan-lahan akan memiliki perilaku yang baik sehingga pengaruh dan lingkungan sekolah yang kurang mendidik seperti berkata kasar, mengejek teman dan lain-lain. Selain itu, juga ada pengawasan dan pantauan guru yang ada di sekolah agar peserta didik dapat berkembang dengan baik, karena tidak hanya kegiatan keagamaan saja yang dapat memberi pendidikan akhlak pada peserta didik tapi juga membiasakan sikap tolong menolong dengan teman, tanggung jawab, disiplin dan perbuatan baik lainnya.

\section{METODE PENELITIAN}

Jenis penelitian ini yaitu kuantitatif dengan pendekatan deskriptif yang dinyatakan dalam bentuk deskriptif yaitu data yang digunakan untuk mendeskripsikan atau menjelaskan peristiwa atau suatu kejadian yang terjadi pada saat sekarang dalam bentuk angka-angka (Rukajat, 2018), (Anggito \& Setiawan, 2018). Variabel bebas dalam penelitian ini adalah full day school, sedangkan variabel terikatnya karakter religius. 
Populasi dalam penelitian ini adalah siswa Sekolah Menengah Pertama (SMP) dan siswa Sekolah Menengah Atas (SMA) di SIT Al-Biruni Mandiri Makassar tahun ajaran 2018/2019 yang berjumlah 105 orang siswa, sedangkan sampelnya yaitu sebanyak 83 orang yang diambil dari 6 kelas Sekolah Mengah Pertama (SMP) dan 3 kelas Sekolah Menengah Atas (SMA) ditentukan melalui teknik probability sampling dengan menggunakan sampling acak sederhana (simple random sampling), dengan kriteria informan yaitu siswa yang rajin. Teknik pengumpulan data yang dilakukan yaitu kuesioner/ angket, observasi, dan dokumentasi. Teknik analisis data menggunakan uji prasyarat analisis yaitu uji nomalitas, uji homogenitas, uji parsial (uji T), analisis regresi sederhana dan analisis korelasi linier.

\section{HASIL PENELITIAN \& PEMBAHASAN}

Berdasarkan temuan hasil penelitian dalam bentuk kuosiner/ angket, observasi dan dokumentasi yang kemudian dilakukan analisis data dari temuan hasil penelitian. Agar terperinci dan terurai, maka dalam pembahasan ini akan disajikan sesuai dengan permasalahan yang diteliti.

Dalam pelaksanaan sistem full day school proses belajar mengajar yang diberlakukan dari pagi sampai sore yang berarti hampir seluruh aktifitas anak berada di sekolah, mulai dari belajar, makan, bermain dan ibadah yang dikemas dalam sistem pendidikan. Melalui sistem ini pula diharapkan mampu memberikan nilai-nilai kehidupan yang Islam pada anak secara utuh dan terintegrasi dalam tujuan pendidikan

Dalam full day school kegiatan-kegiatan belajar seperti tugas sekolah yang biasanya dikerjakan di rumah dapat dikerjakan di sekolah dengan bimbingan guru yang bertugas. Namun bukan berarti full day school mengekang siswa untuk tidak bermain dan terus menerus belajar, tetapi dalam full day school juga terdapat metode dan media belajar yang meliputi kelas dan alam sehingga siswa tidak menjadi bosan. Adanya sistem full day school, lamanya waktu pembelajaran tidak menjadi beban karena sebagian waktunya digunakan untuk waktu-waktu informal. Pelaksanaan full day school menerapkan Pembelajaran yang Aktif, Inovatif, Kreatif, Efektif dan Menyenangkan sehingga siswa tidak akan mengalami kejenuhan dalam kegiatan pelaksanaan pembelajaran.

Dalam program full day school siswa mendapatkan keuntungan secara akademik dimana dengan lamanya waktu belajar siswa dapat menambah pengalaman dan keuntungan secara sosial. Adanya full day school menunjukkan anak-anak lebih banyak belajar daripada bermain. Hal ini menunjukkan produktifitas anak tinggi, maka juga lebih mungkin dekat dengan guru, siswa lebih menunjukkan sikap yang lebih positif, karena tidak ada waktu luang untuk melakukan penyimpangan-penyimpangan karena seharian berada di sekolah dan berada dalam pengawasan guru.

Dalam rangka memaksimalkan waktu luang anak-anak agar lebih berguna, maka diterapkanlah sistem full day school dengan tujuan pembentukan akhlak dan akidah dalam menanamkan nilai-nilai yang positif, serta memberikan dasar kuat dalam belajar disegala aspek. Agar semua dapat terakomodir, kurikulum dalam sistem full day school didesain untuk menjangkau masing-masing bagian dari perkembangan siswa.

Dalam program full day school tujuan pelaksanaan ada dua tujuan utama. Pertama adalah memberikan dasar yang kuat terhadap siswa dan kedua adalah untuk mengembangkan minat dan bakat serta meningkatkan kecerdasan siswa dalam segala aspeknya. 


\section{Jurnal Sosialisasi \\ Jurnal Hasil Pemikiran, Penelitian, dan Pengembangan Keilmuan Sosiologi Pendidikan \\ Vol 7, Nomor 3, November 2020}

Pentingnya pendidikan berbasis religius bagi anak didik di sekolah harus menjadi komitmen bersama dari semua pihak, terutama orangtua, guru, stakeholder pendidikan, dan pemerintah dalam mendorong iklim dan suasana belajar yang menyenangkan dan tidak menimbulkan tekanan psikologis yang dapat berujung pada sikap agresif maupun refresif. Dalam memberdayakan pendidikan agama, perlu mereformasi pendidikan yang selama ini lebih menekankan aspek kognitif dan mengabaikan aspek afektif (sikap, minat, nilai, apresiasi, motivasi) serta aspek kognitif.

Hal tersebut ditunjukkan dari hasil analisis product moment sebesar 0,751 dibandingkan dengan $\mathrm{r}$ _tabel tingkat signifikan 5\% $\mathrm{N}=83$ sebesar 0,215. Jadi $\mathrm{r}$ _hitung besar dari $\mathrm{r}$ tabel, maka dapat ditarik bahwa hipotesis nol $(\mathrm{Ho})$ ditolak dan $(\mathrm{H \alpha})$ diterima. Koefisien determinasi variabel $\mathrm{X}$ terhadap variabel $\mathrm{Y}$ sebesar $56,40 \%$ dan selebihnya yang $43,6 \%$, ini berarti sistem full day school berperan dalam pembentukan sikap religius siswa akan tetapi ada beberapa yang dipengaruhi oleh faktor lain yang tidak diteliti oleh penulis.

Dari hasil analisis uji t diketahui bahwa ada pengaruh yang signifikan variabel $\mathrm{X}$ (full day school) dan variabel Y (Religius). Hal ini dilakukan dengan hasil perhitungan uji $t$ sebesar 10,235, sedangkan pada t_tabel adalah 1,989 pada tarif signifikansi 5\% yang berarti bahwa $\mathrm{H} \alpha$ diterima yaitu: Ada pengaruh yang signifikan antara sistem pembelajaran full day school terhadap pembentukan karakter religius siswa SIT Al-Biruni Mandiri Makassar dan menolak Ho yaitu: Tidak ada pengaruh yang signifikan antara sistem pembelajaran full day school terhadap pembentukan karakter religius siswa SIT Al-Biruni Mandiri Makassar. Hasil penelitian ini sejalan dengan penelitian (Rohana, 2017), (Noriyawati, 2017), dan (Setyaningsih, 2020) yang menyatakan bahwa full day school berpengaruh signifikan terhadap karakter religius.

(Rohana, 2017) menyatakan "Melihat kemandirian siswa dalam melaksanakan ibadah menandakan anak sudah memiliki karakter religius. Walaupun masih ada beberapa yang belum mandiri dalam beribadah. Namun secara keseluruhan siswa memiliki karakter religius dengan tingkat religiusitas yang berbeda-beda antara siswa satu dengan siswa yang lainnya". Besarnya pengaruh yang diberikan sistem full day school terhadap pembentukan karakter religius siswa kelas V SD Nasima Semarang adalah sebesar 51,8\%. Angka tersebut nilai $\mathrm{R}$ square pada tabel regresi model summary. Sisanya sebanyak 48,2\% dipengaruhi oleh faktor lain yang tidak diteliti dalam penelitian ini.

(Noriyawati, 2017) menyatakan "kedua variabel sama-sama mempunyai distribusi yang tinggi pada tingkat kategori cukup baik. Dilihat dari perbandingan perolehan skor responden di setiap variabel menunjukkan bahwa ada perbedaan nilai. Perbedaan tersebut pada kategori pada setiap variabel. Beberapa responden mendapatkan hasil skor sistem full day school baik dan mendapatkan hasil skor tidak baik. Sistem full day school berperan dalam pembentukan sikap religius akan tetapi terkadang kondisi lingkungan yang juga dapat mempengaruhi sikap religius siswa. Besanya pengaruh sistem full day school (X) terhadap sikap religius siswa (Y). hal tersebut juga dapat ditunjukkan $\mathrm{Y}=114,624+0,455$ $\mathrm{X}$ dan koefisien determinasi (R Square) sebesar 0,228 atau sama dengan 22,8\%. Angka tersebut mengandung arti bahwa sistem full day school berpengaruh terhadap sikap religius sebesar $22,8 \%$. Sedangkan sisanya $77,2 \%$ dipengaruhi oleh variabel lain di luar model regresi ini.

(Setyaningsih, 2020) menyatakan "pertama, proses pembentukan karakter siswa dilakukan dengan program sekolah yang meliputi shalat berjamaah, qi' roah wa tahfidz quran, serta kegiatan agama lainnya, kegiatan ketertiban meliputi berangkat sekolah, dan piket kelas, kemudian kegiatan pembelajaran yang meliputi tertib belajar, pelaksanaan 
ujian dan menjaga keberhasilan kelas, selanjutnya melalui kegiatan spontan seperti kebiasaan senyum dan salam, mengucapkan permisidan terima kasih. Selain itu, metode yang sering digunakan dalam pembentukan karakter tersebut, yaitu metode keteladaan yang sering digunakan untuk membimbing siswa agar selalu melakukan hal yang baik. Kemudian metode pembiasaan sering digunakan untuk menanamkan nilai karakter melalui berbagai pembiasaan. Terakhir metode nasihat yang digunakan untuk menasihati siswa yang melakukan hal kurang baik dan memberi motivasi agar siswa dapat merubah perilakunya. Kedua, keberhasilan pembentukan karakter melalui sistem full day school ditunjukan dengan tercapainya beberapa tujuan pendidikan yang telah dirancang oleh sekolah. Kemudian ditunjukan dengan beberapa terbentuknya nilai karakter sebagai berikut: religius, kejujuran, kemandirian, kedisiplinan, komunikatif, peduli lingkungan, dan tanggung jawab. Ketiga, faktor mendukung ialah fasilitas, yang memadai, peran guru dan wali kelas serta orangtua, kebiasaan lupa dan kurangnya mengargai waktu".

Apabila ditinjau dari hasil penelitian terdahulu dengan penelitian sekarang, terdapat persamaan yaitu adanya pengaruh yang signifikan antara sistem pembelajaran full day school terhadap pembentukan karakter religius siswa dan menggunakan metode pembiasaan. Sedangkan perbedaannya yaitu faktor lingkungan keluarga terhadap pembentukan sikap religius. Kehidupan keluarga menjadi fase sosialisasi pertama bagi pembentukan sikap keberagamaan seseorang karena merupakan gambaran kehidupan sebelum mengenal kehidupan luar.

Terkait dengan teori yang digunakan dalam penelitian ini adalah teori struktural fungsional dari Talcott Parsons. Jika dikaitkan dengan penelitian mengenai pengaruh sistem pembelajaran full day school terhadap pembentukan karakter relegius siswa. Teori struktural fungsional secara sederhana didefinisikan sebagai suatu sistem yang saling berhubungan satu sama lain, ketika salah satu sistem tidak berfungsi sebagaimana mestinya, maka yang lain juga akan terkena dampak (Turama, 2020). Jika dibawa dalam lingkungan kelas atau sekolah tentunya memiliki beberapa fungsi, dimana ketika guru tidak mampu membuat lingkungan atau sistuasi yang efektif dalam kelas, maka akan berdampak pada siswa baik dalam berkomunikasi maupun dalam menerima pembelajaran dalam kelas. Apabila ini terjadi maka akan ada ketidakseimbangan. Teori ini berperan dengan fokus pada keseimbangan dan ketertiban agar tercapainya suatu hal yang lebih baik kedepannya.

\section{PENUTUP}

Pelaksanaan sistem full day school di SIT Al-Biruni Mandiri Makassar sudah berjalan baik. Mengingat standar mutunya Al-Biruni menerapkan sistem ini menjadikan pengalaman yang lebih untuk sekolah tersebut. Berdasarkan hasil penelitian dapat diambil kesimpulan bahwa dalam penelitian ini ada pengaruh signifikan antara full day school terhadap karakter Religius pada siswa SIT Al-Biruni Mandiri Makassar. Hal tersebut ditunjukkan dari hasil analisis product moment sebesar 0,751 dibandingkan dengan r_tabel tingkat signifikan 5\% N=83 sebesar 0,215. Jadi r_hitung besar dari $\mathrm{r}$ _tabel, maka dapat ditarik bahwa hipotesis nol (Ho) ditolak dan $(\mathrm{H} \alpha)$ diterima. Dengan koefisien determinasi variabel $X$ terhadap variabel $Y$ sebesar $56,40 \%$ dan selebihnya yang 43,6\%, ini berarti sistem full day school berperan dalam pembentukan sikap religius siswa akan tetapi ada beberapa yang dipengaruhi oleh faktor lain yang tidak diteliti oleh peneliti. Keeratan hubungan antar variabel dapat dilihat dari kooefisien korelasi (tabel correlation atau tabel summary/ nilai R) sebesar 0,751 dan signifikan pada nilai 0,00 (nilai ini lebih kecil dari 
0,05 artinya signifikan). Hal ini memberikan makna bahwa terdapat hubungan antara full day school dengan karakter religius, dan keeratan hubungan antara full day school dengan karakter religius sebesar 0,751 $(75,1 \%)$ dalam kategori hubungan yang kuat.

\section{DAFTAR PUSTAKA}

Anggito, A., \& Setiawan, J. (2018). Metodologi penelitian kualitatif. CV Jejak (Jejak Publisher).

As' ari, H. (2019). Implementasi Kurikulum Program Full Day School Dalam Membentuk Karakter Siswa di SD Muhammadiyah Ponorogo. IAIN Ponorogo.

Asmani, J. M. (2017). Full Day School konsep manajemen \& quality control. Yogyakarta: Ar-Ruzz Media.

Awaru, A. O. T. (2017). Membangun Karakter Bangsa Melalui Pendidikan Berbasis Multikultural Di Sekolah. Prosiding Seminar Nasional Himpunan Sarjana Ilmu-Ilmu Sosial, 2, 221-230.

Awaru, A. O. T., Wilopo, A., Akib, H., Saggaf, M. S., Salam, R., \& Baharuddin, A. (2020). The role of topnotch leaders in fostering employee creative behavior. Solid State Technology, 63(4), 977-980.

Gunawan, H. (2012). Pendidikan karakter. Bandung: Alfabeta, 2.

Noriyawati, N. (2017). Pengaruh sistem Full Day School terhadap sikap Religius siswa di Sekolah Dasar Islamic Global School Sukun Malang. Universitas Islam Negeri Maulana Malik Ibrahim.

Rohana, H. D. (2017). Pengaruh Sistem Full Day School Terhadap Pembentukan Karakter Religius Siswa Kelas V Di SD Nasima Semarang. Universitas Negeri Semarang.

Rukajat, A. (2018). Pendekatan Penelitian Kuantitatif: Quantitative Research Approach. Deepublish.

Setyaningsih, M. (2020). Implementasi Sistem Full Day School Dalam Penguatan Pendidikan Karakter Religius dan Jujur Siswa di SD PTQ Annida Salatiga Tahun 2019/2020. IAIN SALATIGA.

Setyawati, N. A., \& Torro, S. (2017). Full Day School (Studi Kasus Orang Tua Siswa SMA Se-Kota Makassar). Jurnal sosialisasi, 100-105.

Turama, a. R. (2020). Formulasi Teori Fungsionalisme Struktural Talcott Parsons. Eufoni, 2(2).

Umah, C. (2018). Pembinaan akhlak melalui program full day school: Studi kasus di MTS Surya Buana Malang. Universitas Islam Negeri Maulana Malik Ibrahim.

Zubaedi, D. P. K. (2011). Jakarta. Indonesia: Kencana Prenada Media Group. 